\title{
How viruses made us humans
}

Guenther Witzany

The Oxford Handbook of Human Symbolic Evolution

Edited by Nathalie Gontier, Andy Lock, and Chris Sinha

Subject: Psychology, Cognitive Psychology, Cognitive Neuroscience

Online Publication Date: Apr 2021 DOI: 10.1093/oxfordhb/9780198813781.013.5

\begin{abstract}
Keywords
Current research on the origin of DNA and RNA, viruses, and mobile genetic elements prompts a re-evaluation of the origin and nature of genetic material as the driving force behind evolutionary novelty. While scholars used to think that novel features resulted from random genetic mutations of an individual's specific genome, today we recognize the important role that acquired viruses and mobile genetic elements have played in introducing evolutionary novelty within the genomes of species. Viral infections and subviral RNAs can enter the host genome and persist as genetic regulatory networks. Persistent viral infections are also important to understand the split between great apes and humans. Nearly all mammals and nonhuman primates rely on olfaction, i.e., chemoreception as the basis of the sense of smell for social recognition, group membership, and the coordination of organized social life. Humans, however, evolved other means to establish social bonding, because several infection waves by endogenous retroviruses caused a loss of odor receptors in human ancestors. The human independence from olfaction for social recognition was in turn one driver of the rather abrupt human transition to dependence on visual information, gesture production, and facial recognition that are at the roots of language-based communication.
\end{abstract}

Keywords: viruses, genetic regulation, genome editors, olfaction, social recognition, group membership

In modern humans, the mind, not the genome, became the substrate for learned (acquired) group identity, aided by the development of reading. It is with our minds, not our noses, that we learn to belong.

(Villarreal, 2009a)

\section{Introduction}

In the first part, I provide a brief outline of the origin of the biocommunication theory that is to be situated in the pragmatic turn in linguistics and philosophy of science. I then

Page 1 of 19

PRINTED FROM OXFORD HANDBOOKS ONLINE (www.oxfordhandbooks.com). (c) Oxford University Press, 2018. All Rights Reserved. Under the terms of the licence agreement, an individual user may print out a PDF of a single chapter of a title in Oxford Handbooks Online for personal use (for details see Privacy Policy and Legal Notice). 


\section{How viruses made us humans}

demonstrate how the biocommunication approach can help explain the origin of sign mediated interactions in all three domains of life.

In the second part of this chapter, I focus on how genetic material can be understood as a natural code and how viral genes infiltrate mammalian and human genomes. Viral infections are key players in the evolution of all cellular organisms in general and mammals in particular. Endogenous retroviruses in particular have played a crucial role in the evolution of the placenta, and they are also responsible for the loss of odor, especially in humans. As we shall see, the latter provides a means to understand the evolution of human bonding and social communication in the form of symbolic language.

\section{Example: The emergence of meaning in natur- al languages}

"Anything that can be said can be said clearly" (Wittgenstein, 1922). This is a quote from the philosopher Ludwig Wittgenstein's Tractatus Logico Philosophicus. The book investigated how language refers to the world and how it enables scientific knowledge to be expressed in a formal, logical language. Wittgenstein tried to find and justify a strict mathematical theory of language, where all sentences of science can be formalized and expressed as mathematical-like equations. For that reason, he argued that what can be said scientifically can be said clearly. Sentences that cannot be formalized are deemed scientifically senseless.

In his later works, Wittgenstein (1953) rejected his earlier ideal of a world-depicting, formal universal language. Instead, he recognized that the basic features of natural languages are determined by social groups that use a limited repertoire of signs for social interactions. The later Wittgenstein argued it is the social and pragmatic context in which the living agent is concretely interwoven that determines the meaning (function) of a sign-sequence of a natural language.

This idea marks the pragmatic turn in philosophy of science, of which earlier proponents include Charles Sanders Peirce (1923, p. 87), who said that to identify "meaning ... we have to identify the habits it produces." Peirce introduced the term semiotics to designate the science of signs. He differentiated three classes of sign. Indices point to some object in the context in which it occurs, an example being a footprint in the sand. Icons are signs that demonstrate similarity with the designated object; think of the image in front of public toilets with the different icons of females and males. Symbols, the third class of signs, do not depict what they express, for example, the alphabetical letters of a human language are symbols for sounds. In pragmatics, the connection between a symbol and its meaning does not depend upon the relation between the symbol and the object, but results from convention-based social learning.

George Herbert Mead demonstrated that meaning (semantics) is a social event, a social interaction-derived consensus. This contradicts the core concept of the (coding) sender

Page 2 of 19

PRINTED FROM OXFORD HANDBOOKS ONLINE (www.oxfordhandbooks.com). (C) Oxford University Press, 2018. All Rights Reserved. Under the terms of the licence agreement, an individual user may print out a PDF of a single chapter of a title in Oxford Handbooks Online for personal use (for details see Privacy Policy and Legal Notice). 


\section{How viruses made us humans}

(and the decoding) receiver narratives (see below) which cannot explain how communicating living agents reach a common agreement on the meaning of signs and the goals of cooperation. Later proponents of the pragmatic turn included John Langshaw Austin (1975) and John Searle (1976) who developed the speech act theory, as well as Jürgen Habermas $(1984,1987)$ who introduced the theory of communicative action.

Major insights on human language and communication can be summarized in terms of the following points (Witzany, 2010a).

- Language is a repertoire of signs that is used by competent agents according to syntactic (combinatorial), pragmatic (context dependent), and semantic (content coherent) rules. Any system that lacks either syntax, semantics, or pragmatic language use cannot be defined as language.

- We may differentiate between a linguistic competence (to generate sentences) and a communicative competence (to induce social interactions).

- Languages are not sui generis. There must be groups of living agents that share the above-mentioned rules and competences in generating utterances using commonly shared signs. This means that natural language use is inherently a social event. Thinking (in sign-based sentence-like structures) follows the social learning of language and not the other way around.

- Language is primarily used for communicative interactions. Communication in everyday life is not restricted to transfer of factual knowledge about the world. Rather, it assembles all social interactions/knowledge that are mediated by signs. Non-verbal bodily expressions may also serve as signs, and when combined they too bring forth communicative interactions (e.g., gestures, mimesis, or pantomime).

- In addition to denoting various classes of speech acts, natural language is also innovative because it enables the generation of new sequences, new behavior, and new interactional patterns. The results of such innovative speech acts cannot be predicted from a complete analysis of former behaviors or former sentences or words, i.e., they cannot be computed in principle.

These points about natural language use have now been empirically validated (see Habermas, 1984, 1987; Tomasello et al., 2005) and they contradict the core assumptions made by classic theories, including mathematical theories of language that assume that language refers to outer objects, as well as its derivatives that include information theory (Shannon \& Weaver, 1949), systems theory (Wiener, 1948; von Neumann, 1966), and Chomsky's theory (Chomsky, 1964; Nowak et al., 2001) on generative grammar.

In the remainder of this chapter I integrate and develop these insights brought forth by the overall pragmatic turn to language and communication.

Page 3 of 19

PRINTED FROM OXFORD HANDBOOKS ONLINE (www.oxfordhandbooks.com). (c) Oxford University Press, 2018. All Rights Reserved. Under the terms of the licence agreement, an individual user may print out a PDF of a single chapter of a title in Oxford Handbooks Online for personal use (for details see Privacy Policy and Legal Notice). 


\title{
Biocommunication at all levels in all domains of life
}

\begin{abstract}
All known living organisms can be categorized into three domains: archae, bacteria (together called prokaryotes), and eukaryotes. Eukaryotes are all organisms, uni- or multicellular, that have a nucleus where genes are organized on chromosomes. Prokaryotes do not have nuclei and many are unicellular although they may form colonies and bacterial mats.
\end{abstract}

From archaea, bacteria, and unicellular eukaryotes up to the more complex eukaryotes, such as fungi, plants, and animals, all life forms have a sign repertoire to coordinate and organize the life processes within and between different organisms. Abundance of empirical data provide us with insights into communicative interactions at the basis of all coordinated cell processes within and between cells in nearly all situational contexts (Witzany, 2010a, 2011, 2012a, b, 2014, 2017a, 2020; Witzany \& Baluska 2012; Witzany \& Nowacki, 2016).

A well-known example is the research by Karl von Frisch into the communication strategies bees use to coordinate their common behavior and to organize reproduction and food gathering. Controversially, he claimed that the terminology of "bee languages" is not merely metaphorical, and that bee communication systems have all the attributes of real languages, including a variety of dialects (Frisch, 1971).

von Frisch's research motivated me to investigate all the domains of life, to establish whether language use in communication processes is a rather exceptional phenomenon, or on the contrary, is the main characteristic of life (Witzany, 2019) in organizing and coordinating interactions between cells, tissues, organs, and organisms. Figure 1 gives a graphic representation of the resulting theory of biocommunication.

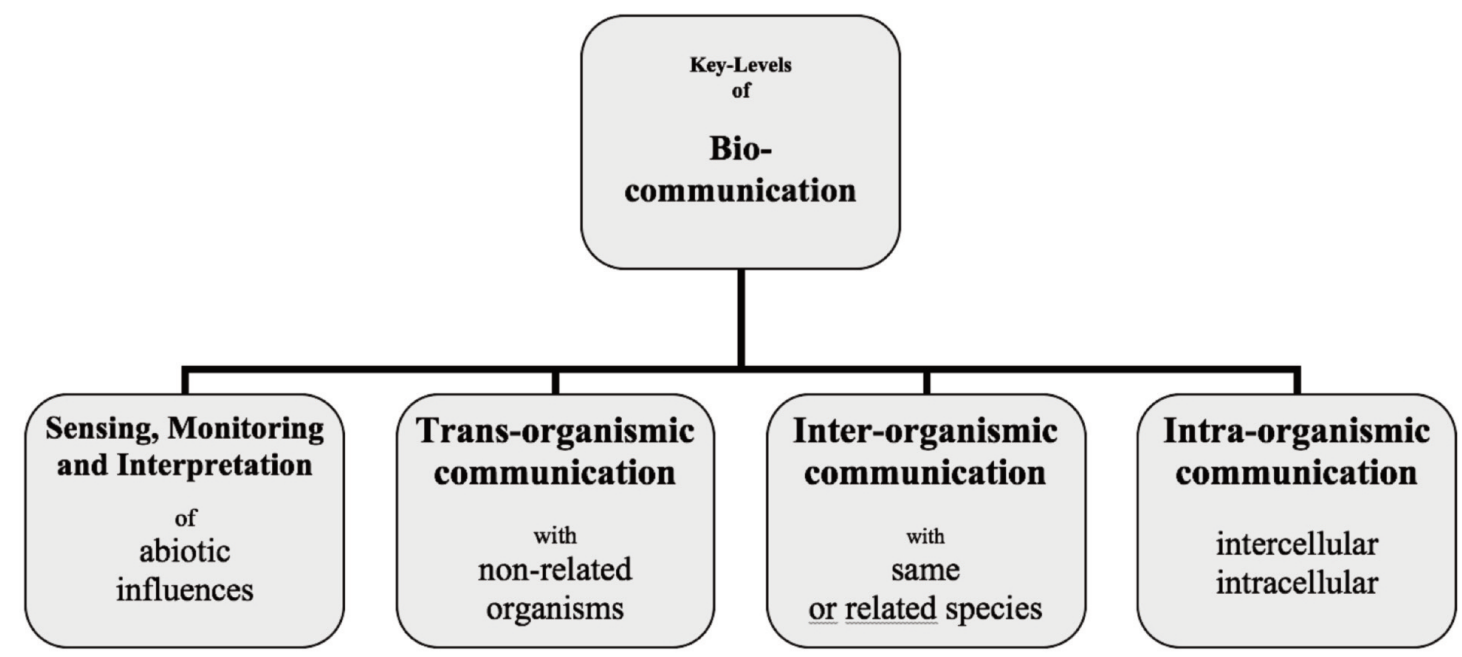

Figure 1: The biocommunication approach identified four levels in which cellular organisms are involved since the start of their life until death. 


\section{The genetic code: A natural language?}

Molecular biologists characterize genes as representing a natural code, where transcription processes from DNA to RNA, and translation processes from RNA to amino acids and proteins, as well as immune responses, and cell-cell communication are the essential processes of how organismic form comes about. These concepts were not introduced into biochemistry and molecular biology by linguists, communication experts, or language philosophers; they were coined by molecular biologists to explain observed phenomena (Nirenberg et al., 1965; Crick, 1968).

Nobel laureate Manfred Eigen insisted that the genetic code represents a real language and that the term "language" is not just a metaphor. "All the words of the molecular language are combined to a meaningful text, which can be broken down into sentences" (Eigen \& Winkler, 1983, p. 305). "At any rate one can say that the prerequisite for both great evolutionary processes of nature-the origin of all forms of life and the evolution of the mind-was the existence of a language" (p. 314). Nonetheless, Eigen understood language as it was defined by Chomsky, in terms of a context-free universal grammar where the meaning (semantics) of any given language sequence is determined by its syntax.

Clearly, the nucleic acid language and the protein language are rather different from cellular organisms that communicate with their repertoire of signs. On the other hand, if we take seriously the idea that no natural language speaks itself, just as no natural code codes itself but depends on competent social interacting agents, we have to identify agents that edit, modify, adapt, or generate genetic code sequences de novo. What are these agents, where do they live, and what are their main behavioral motifs?

\section{Viruses and RNA networks act as natural edi- tors of genetic text}

Because they lack metabolism, scholars debate whether viruses can really be considered to be life forms. One thing is for sure, however: viruses contain many genes which are unique to viruses and thus not found in any living organism. Some virologists therefore suggest viruses predated cellular organisms. The number of genes found in viruses and virus-derived parts exceeds by a factor of ten the amount of genetic information found in cellular organisms. If we ignore eukaryotes and only consider prokaryotic life, we have a number of prokaryote viruses of $10^{31}$, which means if we were to line up the length of their virions, we would have a string of length forty million light years (Rohwer et al., 2014).

One way in which we can conceptualize this finding is by understanding that the visible living world of organisms belonging to the three domains are embedded into a viral "dark matter" that we are only just beginning to examine (Youle et al., 2012). Most of these viruses and virus-like genetic agents do not cause diseases, but they persistently colonize

Page 5 of 19

PRINTED FROM OXFORD HANDBOOKS ONLINE (www.oxfordhandbooks.com). (C) Oxford University Press, 2018. All Rights Reserved. Under the terms of the licence agreement, an individual user may print out a PDF of a single chapter of a title in Oxford Handbooks Online for personal use (for details see Privacy Policy and Legal Notice).

Subscriber: OUP-Reference Gratis Access; date: 15 April 2021 


\section{How viruses made us humans}

host cells and host genomes (Villarreal, 2005). When viruses colonize host cells, a key feature is that only a few persist as functional agents. In most cases, viruses undergo loss of function and in a later phase, these "defectives" are co-opted by the cell. Here they contribute to all steps and sub-steps in cellular functions such as transcription, translation, epigenetic markings, repair, and immunity (Villarreal, 2009a,b; 2011a; Ryan, 2009; Villarreal \& Witzany, 2010).

There exist millions of types of viruses. Examples are bacteriophages, DNA, or RNA viruses. Particularly important for this discussion is the group called endogenous retroviruses, which are viruses that specifically infiltrate the genomes of mammals; and a subclass of endogenous retroviruses, human endogenous retroviruses, that are found inside human genomes. Besides viruses, there also exist a whole series of mobile genetic elements some of which might be related by common descent to these viruses, and others of which we do not yet know their evolutionary origin.

Many of these viruses nest themselves in the areas of the genome that used to be designated as "junk DNA" because these genes do not encode for proteins. However, today we know that non-coding RNAs regulate key functions in the cells they belong to. In the human genome, for example, approximately 2 percent of the genetic sequences code for proteins that underlie development and growth of the organismic body; the remaining 98 percent is non-coding DNA that is nonetheless transcribed in non-coding RNA performing various regulatory functions (Witzany, 2010b).

This means that DNA is not merely a genetic storage medium serving as a heritable "blueprint" and evolutionary protocol, it is also a species-specific ecological niche. The human genome, for example, is colonized by retrovirus-derived retroposons and other mobile genetic elements, which in total sum represent more than 60 percent of the whole genetic content of humans (de Koning et al., 2011).

In sum, viruses and mobile genetic elements infect organisms and insert themselves into host genomes, thereby disrupting the existing sequence. They can, for example, delete existing host sequences, or they can multiply within the host system through a copy-andpaste technique (Shapiro, 2002; Shapiro \& Sternberg, 2005). They furthermore change host genetic identities either by recombination or by the epigenetic (re)regulation of genetic content, and many co-evolve with the host and interact in a module-like manner (Villarreal \& Witzany, 2015). In this respect viruses play vital roles in evolutionary and developmental processes (Weiner, 2006; Villarreal, 2015a; Roossinck, 2015). In contrast to accidental point mutations, their integration at various preferred sites is not a randomly occurring process, but is coherent with the genetic content of the host; otherwise, important protein coding regions would be damaged, causing disease or even lethal consequences for the host organism. Such biological agents are capable of identifying sequence-specific loci of genetic text (Bushman, 2003; Mitchell et al., 2004; Lambowitz \& Zimmerly, 2011). They are masters of the shared technique of coherently identifying and combining nucleotides according to contextual needs. This natural genome editing competence is absent in abiotic life, and therefore represents a core capability of life.

Page 6 of 19

PRINTED FROM OXFORD HANDBOOKS ONLINE (www.oxfordhandbooks.com). (c) Oxford University Press, 2018. All Rights Reserved. Under the terms of the licence agreement, an individual user may print out a PDF of a single chapter of a title in Oxford Handbooks Online for personal use (for details see Privacy Policy and Legal Notice). 


\section{How viruses made us humans}

These examples show that the genome is not merely a molecular structure with a storage function, but rather an ecosphere habitat with an abundance of RNA-derived settlers such as retroviruses, competing for a limited resource: DNA. To get access to this limited resource some cooperative behavioral patterns have been selected whereby formerly competing agents find a way to cooperate and to counter-regulate within the host genome. This newly emerging cooperation of formerly competing genetic parasites may lead to new features in host tissues, organs, or organisms, as documented in the various innate and adaptive immune systems (Marraffini \& Sontheimer, 2010; Villarreal, 2009b). It is possible to imagine how different tissue types evolved in quite different species; this is a coherent event because of an abundance of persistent (non-lytic) viruses which share tissue specificity rather than species specificity (Villarreal, 2009a).

\section{The role of retroviruses in the evolution of the mammalian placenta}

Up to one hundred genes can transfer to a new host in a single infection event. This is not a small step, as is the case with replication errors (chance mutations), but an evolutionary non-random drive with far-reaching consequences. An example relevant for mammalian and human evolution are endogenous retroviral infections that lead to the transfer of syncytin genes, which resulted in the evolutionary novelty of placental mammals (Perot et al., 2012).

The most active period of an endogenous retroviral transcription occurs during the formation of placental tissue, during growth periods, and when trophoblasts join together (Villarreal, 2004, p. 314). Trophoblasts encapsulate the fertilized egg, help the egg nest properly, trigger processes that ensure nutrition, and prevent reactive responses by the mother's own immune system. The egg is therefore protected by trophoblasts against an immuno-reactive response of the mother. These characteristics are unknown to monotreme mammals and marsupials.

In turn, the trophectoderm is a highly complex tissue that is, surprisingly, not of maternal origin, but a derivative of the fertilized egg. It develops before the egg becomes implanted into the uteral lining. Experimentally suppressed expression of endogenous retroviruses inhibits implantation (Villarreal, 2015b). This implies that implantation of the embryo requires transcription of retroviral syncytin-coding genes. In humans, the HERV W env gene codes for syncytin (Dupressoir et al., 2005), a molecule used by the host to join trophoblast cells with the tissue that eventually nourishes the embryo (Villarreal, 2004).

Although these processes have been known for over thirty years, the purpose of this reaction was previously unclear: it did not make sense that the evolutionary innovation of placental mammals was tied to the acquisition of a complex set of endogenous retroviruses. Since the trophectoderm is protected by the maternal immune system, it enables further growth into the placenta, thereby modifying blood flow and nutrient supply between mother and embryo. Once the sex of the totipotent embryo is determined, the high ERV

Page 7 of 19

PRINTED FROM OXFORD HANDBOOKS ONLINE (www.oxfordhandbooks.com). (c) Oxford University Press, 2018. All Rights Reserved. Under the terms of the licence agreement, an individual user may print out a PDF of a single chapter of a title in Oxford Handbooks Online for personal use (for details see Privacy Policy and Legal Notice). 


\section{How viruses made us humans}

expression rates are stopped and DNA methylation functions again (Villarreal, 2005, p. 325).

Microbiological infection events may also, however, lead to genetic defects also, perhaps leading to the loss of relevant tissues. As we will see later this means that such colonizers might also destroy important genetic sources, in turn driving the evolution of alternative capabilities.

\section{The cooperative turn in humans}

Viruses and subviral RNA networks also underlie key differences between human and nonhuman primate communication. Here we focus on the evolutionary dynamics that led to symbol generation and usage (Burling, 2005). Cooperation and intentionality are hallmarks of complex nonhuman primate communication systems: but human languages are different. Great apes understand many aspects of social interactions in their life worlds, including causal and intentional relationships (Russon \& Begun, 2004). But in contrast to human infants, great apes cannot participate in shared intentionality or cooperative communication (Tomasello \& Rakoczy, 2003).

The intentionality displayed by chimpanzees and bonobos includes the capacity for goaloriented behavior, including the imagining of a possible action and its results, especially if similar situations have previously been experienced. We can characterize such goal-oriented behavior as "cognitive" because a chimpanzee such as bonobo not only observes its conspecifics and the larger environment, but also employs inner simulation, i.e., self-observation (Hobaiter \& Byrne, 2014). Although chimpanzees and bonobos use a wide range of manual gestures to communicate, they only communicate about real-life situations, and only in a context where communication leads to immediate manipulations of social situations (Graham et al., 2018; Bohn et al., 2016). Conclusions in the context of a great ape's life refer to real-life or actual situations, not probable or fantastic ones (Byrne et al., 2017). Apes do not produce gestures to draw attention to situations or entities that are not actual, or to inform another ape without intending to manipulate its behavior (Graham et al., 2018; Bohn et al., 2016).

The shared intentionality and social lifestyle engaged in by humans surpasses that of great apes, and human language requires higher-order theory of mind (Tomasello, 2008). Human social cognition is characterized by shared intentionality that brings forth cooperative and altruistic interactions, potentiating new modes of cognitive representation such as making perspective-taking and symbolism possible (Tomasello, 2003a,b). Socially recursive cognitive behavior resulted in humans not merely focusing on individual perspectives but on the perspective of other group members (Tomasello, 2008).

This new form of cooperation based upon shared intentionality emerged from common goals and shared attention. Group hunting in great apes is characterized by each individual ape trying to catch the prey. This means the group behavior remains in the "ego-status" for every individual. But the so-called cooperative turn in humans means that the

Page 8 of 19

PRINTED FROM OXFORD HANDBOOKS ONLINE (www.oxfordhandbooks.com). (c) Oxford University Press, 2018. All Rights Reserved. Under the terms of the licence agreement, an individual user may print out a PDF of a single chapter of a title in Oxford Handbooks Online for personal use (for details see Privacy Policy and Legal Notice). 


\section{How viruses made us humans}

group members now act in a group perspective without "ego-status" (Tomasello, 2008). The decisions that are taken focus on group rather than individual benefits. This can already be seen in three-year-old children who have been shown to engage in cooperation in experimental situations (Liszkowski et al., 2009). It was demonstrated that the shared goal is so important that individual children who reached their goals early did not stop their actions until all the others had reached their goals. Similar behavior in great apes has not been observed.

\section{Cultural background as collective intentionality}

Culture assembles a totality of specific self-reflexive cognitive actions combining shared intentionality with knowledge of different perspectives on common goals (Tomasello \& Rakoczy, 2003). This differs from great ape cognition which focuses on common goals rather than from an "ego-status." With human-shared intentionality a new evolutionary stage has emerged. Individuals that act on their "ego-status" in the group now depend on each other by sharing cooperative goals. This crucially includes helping another group member by giving information that is beneficial for the other, but not necessarily for the information-giving agent. A central communication motif arises here: giving others useful information for their benefit. This new motif is not found in great ape communication (Tomasello et al., 2005).

Human groups now build cultural identities (self/non-self culture) with a variety of cultural conventions, norms, and institutions that are not constituted by individual but by a culturally shared background. This cultural background and the experiences within everyday life represent knowledge within a teaching process for future generations, which should integrate every new member from birth onwards into these norms of a specific cultural identity. Children are actively told and taught in an altruistic way to learn all these behavioral motifs of the specific culture, to internalize them, and to become fully responsible members of this cultural group.

Language types no longer have personal connections with expressed utterance types. Rather, communicative conventions decide whether one uses a word in a correct sense or not. Now, every new member of the human species from childhood onwards (as a part of the cultural identity group) can learn a "universe" of conventionalized communication (Tomasello, 1999, 2014).

How did humans evolve gestures to draw attention to situations or entities that are not actual, and why do they willingly share information with other group members without the immediate intention to manipulate their social world? In other words, how do gestures and vocalizations transition from being merely iconic and indexical to being symbolic? As we saw, symbols are signs that neither "pick out" nor depict what they mean. Rather, they result from conventions that are memorized, learned, and used in a correct or incorrect way (Gillespie-Lynch et al., 2014). The use of symbols requires certain levels of abstraction: if humans speak about something that is not real, they extend time and space beyond the immediately present (Tomasello, 2003a,b; 2008).

Page 9 of 19

PRINTED FROM OXFORD HANDBOOKS ONLINE (www.oxfordhandbooks.com). (c) Oxford University Press, 2018. All Rights Reserved. Under the terms of the licence agreement, an individual user may print out a PDF of a single chapter of a title in Oxford Handbooks Online for personal use (for details see Privacy Policy and Legal Notice). 


\section{How viruses made us humans}

In summary, human language emerges from human communication, i.e., sign-mediated interactions as an essential means to coordinate and organize all common goals based on commonly shared conventions, understanding, and intentions. As we have seen, children in human societies learn how to use language by combining words and utterances within the context of everyday social life. The learning process is embedded in cultural traditions, based on local customs and traditions that include religious and moral systems. All aspects of learning are inculcated socially, because the meanings of linguistic utterances are not a private but social (Mead, 1934). There must have been an evolutionary pathway to the emergence of this capability. It has often been assumed that the evolution of symbolization results from stochastic genetic mutations that bring forth an invention, an evolutionary upgrade, so to speak, of existing capacities. Here, we provide an alternative view to explain the transition from iconic and indexical to symbolic behavior.

\section{Social sensing in most mammals is determined by pheromone com- munication}

How do other mammals, and nonhuman primates in particular, learn social behavior? How do they acquire competence in social interactions, and learn their social roles in their community? How do they appropriate behavior that enables social integration within their community? What are the consequences of single failures or repeated failures in social interaction?

The basic identity sharing system in animals, especially in mammals, is pheromone-based. Pheromones are intense odors brought forth by biochemical processes, for which mammals have evolved the sense of smell. We know that the pheromone sensory systems and receptors are evolutionary very old, being essential communication tools even for bacteria. Pheromones are key semiochemicals for identifying other animals. For marsupials, rodents, or dogs, for example, urinary odor detection and odor marking is essential amongst competing males, and odor detection by menstruating females is of primary interest for both males and females. While social learning occurs within all animal lineages, the social role of odor sensing is predominant (Villarreal, 2009a, 2011b, 2015b).

Mammalian social identification systems in addition are dependent upon maternal bonding that occurs between a mother and her offspring. Placental mammals need obsession to nurse their young (Gootwine, 2004). In placental mammals the various pheromones that emotionally attach the mother and her young start at the onset of the very development of fetus and continues after birth via lactation and milk. Pheromones, such as oxytocin, vasopressin, or prolactin together with their cognate receptors play essential roles here. This fundamental social bonding system together with facial recognition (pleasure, fear, anger, etc.) and memory is very important and is not subjected to genetic variation processes during the long evolutionary periods. In other words, these biochemical systems are highly conserved. The increasing importance of social bonding correlated with neurobiological complexity (Kendrick, 2006), especially the learning of emotional plea-

Page 10 of 19

PRINTED FROM OXFORD HANDBOOKS ONLINE (www.oxfordhandbooks.com). (c) Oxford University Press, 2018. All Rights Reserved. Under the terms of the licence agreement, an individual user may print out a PDF of a single chapter of a title in Oxford Handbooks Online for personal use (for details see Privacy Policy and Legal Notice). 


\section{How viruses made us humans}

sure or emotional pain for social bonding or loss of social bonding becomes of importance for learning mammals in the earlier stages.

These findings allow us to combine empirical knowledge about neurobiological aspects of human language and communication with knowledge of basic molecular biological processes in microbiology in general and virology in particular, with the goal of understanding how recent research on viruses and subviral RNA networks that shape the genes and genome architecture of all living organisms is relevant for language evolution and the evolution of symbol use. The difference between the nucleotide sequences coding for proteins (amounting to less than 2 percent of the total sum of nucleotides) of humans and their closest ancestors, the chimpanzees, is only 1-2 percent. These small differences cannot explain the enormous inter-species differences in behavior, cognition, and communication. Noncoding DNA regions that are transcribed in reproduction, which do not code for proteins but are for regulatory RNAs-are relevant in nearly all cellular processes. Humans differ the most from chimpanzees in the endogenous retrovirus colonizers (HERV-K), the long terminal repeats (LTRs), and the Y-chromosome (Kim et al., 2004; Flockerzi et al., 2005, Jurka et al., 2007).

The hypothesis I advance is that the primacy of pheromone detection was lost by some African primates, as a consequence of repeated steps of retroviral colonization of their genomes. The genetic alterations caused by retroviral invasion led to damage or even loss of the relevant receptors, olfactory genes, and related tissues; favoring a shift in dominance to other sensory modalities, and in particular, vision and vocalization.

\section{Genetic colonizers divided evolutionary pathways of primates}

The neocortex of humans in comparison to chimpanzees displays a tissue enlargement that depends on stable alterations to the cellular programming and tissue (cell) identity systems involving ancestral neuronal stem cells. Only retroviruses have the capacity for such re-programming, as demonstrated in several tissues e.g., retroviral infection derived arc genes that are essential for long-lasting information storage in the mammalian brain (Shepherd, 2017). Virologist Luis Villarreal developed a plausible scenario from the virusfirst perspective: an epidemic-like colonization by endogenous retroviruses took place within African primates that incapacitated the role of olfaction for recognition of group identity (Villarreal, 2015b). The primary tool to identify group members and their sexual and social roles in everyday group life was abruptly lost. The loss of odor receptors and related tissues was the result of several infection waves by endogenous retroviruses. This caused a dramatic loss of the major histocompatibility complex (MHC) olfaction (Kulski et al., 1999; Spehr et al., 2006; Doxiadis et al., 2008) and finally led to group recognition becoming independent from olfaction, which is the primary source to differentiate individuals of the (self) group and non-self individuals in all other mammals (Villarreal, 2009a). The loss of olfaction-based social recognition caused an increasing and probably abrupt shift to dependence on visual information, including gesture production and recognition, and vocalization.

Page 11 of 19

PRINTED FROM OXFORD HANDBOOKS ONLINE (www.oxfordhandbooks.com). (c) Oxford University Press, 2018. All Rights Reserved. Under the terms of the licence agreement, an individual user may print out a PDF of a single chapter of a title in Oxford Handbooks Online for personal use (for details see Privacy Policy and Legal Notice). 


\section{How viruses made us humans}

After the loss of odor receptors, determining social roles within groups and the language of humans became the dominant tool for social bonding. This means that the pheromonebased social bonding typical of other mammals in humans was replaced by a more complex cognitive process. In association with language-based social bonding, the visual brain cortex must evolve relevantly because prior to language, body expression patterns that served as tools for generating coherent gestural sequences became most important after the loss of odor capabilities (Villarreal, 2009a, 2011b, 2015b).

The newly derived social bonding techniques via visual social interactions, accompanied by vocal complexity and differences in color vision, increased the (mirror-) neuronal communication and its complexity in human social brains. The social brain, therefore, results from group identity procedures and processes (organization and coordination of group behavior). After the HERV K colonization of African primates, which reduced odor reception dramatically in humans, several other colonization waves continued, and further incapacitated the remaining olfactory-based identity (Villarreal, 2009a, 2015b). It is noteworthy too that various behavioral instincts expressed by many mammals immediately after birth are also lost in humans. Humans, in fact, are the most helpless of all the newborn mammals. They can only eat and defecate at birth without additional learning. But, in contrast to all other primates, human infants must learn fundamental movements. They cannot walk, crawl, or even lift their heads.

As a result, human beings are more and more dependent on learning from others, especially during their early brain development phase. Human communication and language were the primary tools for social group identity integration or rejection. The social brains of humans need complex language skills in order to transmit survival strategies to conspecifics, to manufacture and use tools, and to learn the rites and rituals of the community they belong to.

\section{Designation of content that is not actually present by symbol-mediat- ed speech-acts}

Language freed humans from many biological determinants playing major roles in nonhuman primates, but the question of how humans invented symbolic language remains. The differences between human and nonhuman communication is based upon the existence of some kind of extended mind and on emotional networking that is grounded in recursive thinking and feeling and on the capacity to generate and transfer information to others that represents content which is not connected to actual situations. This may be a starting phase for the origin of language-based conventional behavior, new vocal alphabets, symbolic signs, and sign sequences.

Designation of content that is not actually present needs combinations of gestures and vocal sounds that a social community agrees upon in a conventional process, which is not the result of innate expression patterns. The pheromone-based semiochemicals and the main receptor of odor detection employed in nonhuman primate biocommunication, and the related tissues, are almost completely lost in humans due to the retroviral infection

Page 12 of 19

PRINTED FROM OXFORD HANDBOOKS ONLINE (www.oxfordhandbooks.com). (c) Oxford University Press, 2018. All Rights Reserved. Under the terms of the licence agreement, an individual user may print out a PDF of a single chapter of a title in Oxford Handbooks Online for personal use (for details see Privacy Policy and Legal Notice). 


\section{How viruses made us humans}

waves. Therefore, facial recognition and conventional sign use that designates content that is not actually present empowers planning for the future, such as food storage techniques (for winter) not for "ego"-status, but for the common benefit of the group.

Myth telling from the past and cultural traditions, such as group rituals as well as related cults derived techniques, such as painting and music became essential tools in the transgenerational transfer of group memory and learning (Tomasello, 1999; Zilhão et al., 2010; Montagu, 2017; Hoffmann et al., 2018) Symbolic sign use in abstract alphabet use that is traded, learned, and memorized through generations dominates social life of early human species and selection processes.

\section{Conclusions}

Communication is a key characteristic of life in general. The evolution of symbolic language based upon sign-mediated interactions in humans is at least in part the result of an abrupt loss of genetic determinants for identity recognition, and coding for odor receptors and cells of related tissues. These persistent infections of endogenous retroviruses affected African primates in several waves and finally led to the divergent pathway of human evolution. Humans had to rapidly develop new tools to coordinate and organize group identity, group behavior, and social roles. Early human communicative gestures were followed by vocal languages to designate objects and action behavioral motifs (attack, defense, mating, food gathering) even if-most importantly-these were not actual, but distant in time and space. This acted as a pressure to evolve linguistic conventions for conveying shared meanings, based upon a lexicon that goes beyond indexical and iconic signs to symbolic signs. As a successful tool for coordination and organization, that must be reproduced by social learning and memory in myth telling and rituals, symbolic language emerged as a fundamental species-specific trait contributing to human survival.

\section{Glossary}

\section{Non-coding RNAs}

In any cellular replication process DNA sequences are transcribed into intermediate RNA to form the protein coding exon sequences. Some of the transcribed RNAs do not code for proteins and serve as regulatory RNAs such as transfer RNA, messenger RNA, ribosomal RNA, micro RNA, small interfering RNA, small nuclear RNA, small nucleolar RNA, and several other RNAs all being remnants of former infection events by genetic parasites (such as mobile genetic elements) that reached persistent status in host genomes. In, for example, humans only 1.5 percent of the whole genome sequence serves as protein coding sequences whereas 98.5 percent represent sequences that do not code for proteins.

Mobile genetic elements (MGE)

Genetic sequences that may move around the genome and even self replicate. MGEs are remnants of former infection events by genetic parasites such as viruses and their relatives.

Page 13 of 19

PRINTED FROM OXFORD HANDBOOKS ONLINE (www.oxfordhandbooks.com). (c) Oxford University Press, 2018. All Rights Reserved. Under the terms of the licence agreement, an individual user may print out a PDF of a single chapter of a title in Oxford Handbooks Online for personal use (for details see Privacy Policy and Legal Notice). 


\title{
How viruses made us humans
}

\author{
Subviral RNAs \\ Subviral RNAs in most cases are parts of former viruses that remain as regulatory ele- \\ ments in infected host genomes. Some term it "defectives" because in most cases they \\ cannot reassemble to functional viruses. \\ Endogenous retrovirus \\ Endogenous retroviruses are viruses that persist within a host genome without caus- \\ ing disease. Some of them are coadapted and serve as important regulatory elements \\ such as, for example, syncytin in pregnancy. \\ Long terminal repeats (LTRs) \\ Repeat sequences of RNA used by viruses to insert into a host genome. As coadapted \\ genetic sequences they may serve later on in host genomes as essential regulatory ge- \\ netic elements. \\ Phages \\ Originally "bacteriophage," this is a kind of virus that infects bacteria and archaea. \\ Phages are the most numerous and diverse living entities on this planet. \\ Syncytin \\ Syncytin is an essential cell fusion protein in mammals especially in placenta forma- \\ tion and embryo attachment in the uterus. Syncytin is encoded by an endogenous \\ retrovirus, i.e., a former infection derived retrovirus that reached persistent status in \\ the host genome. \\ HERV-K \\ Human endogenous retrovirus besides humans is found also in old world monkeys, \\ great apes. May be associated with cancer in testis but in the case of overexpression \\ may have an immune function against related genetic parasites. \\ Semiochemicals \\ (semeion; Greek: sign) Are molecules that function as signs in communication process- \\ es and are produced by cells, tissues, organs, or organisms to communicate with oth- \\ ers of the same or related identities. Prominent example of semiochemicals are hor- \\ mones. \\ Major histocompatibility complex (MHC) \\ Cell surface proteins that functions in immune systems to identify foreign (non-self) \\ molecules.
}

\section{References}

Austin, J. L. (1975). How to do things with words (J. O Urmson \& M Sbisà (Eds.), original work published 1962). London: Harvard University Press.

Bohn, M., Call, J., \& Tomasello, M. (2016). The role of past interactions in great apes' communication about absent entities. Journal of Comparative Psychology 130, 351-357.

Burling, R. (2005). The talking ape: How language evolved. Oxford: Oxford University Press.

Page 14 of 19

PRINTED FROM OXFORD HANDBOOKS ONLINE (www.oxfordhandbooks.com). (C Oxford University Press, 2018. All Rights Reserved. Under the terms of the licence agreement, an individual user may print out a PDF of a single chapter of a title in Oxford Handbooks Online for personal use (for details see Privacy Policy and Legal Notice). 


\section{How viruses made us humans}

Bushman, F. D. (2003). Targeting survival: Integration site selection by retroviruses and LTR-retrotransposons. Cell 115, 135-138.

Byrne, R. W., Cartmill, E., Genty, E., Graham, K. E., Hobaiter, C., \& Tanner, J. (2017). Great ape gestures: Intentional communication with a rich set of innate signals. Animal Cognition 20, 755-769.

Chomsky, N. (1964). Current issues in linguistic theory. The Hague \& London: Mouton.

Crick, F. (1968). The origin of the genetic code. Journal of Molecular Biology 38, 367-379.

de Koning, A. P. J., Gu, W., Castoe, T. A., Batzer, M. A., \& Pollock, D. D. (2011). Repetitive elements may comprise over two-thirds of the human genome. PLoS Genetics 7(12), 1-12.

Doxiadis, G. G., de Groot, N., \& Bontrop, R. E. (2008). Impact of endogenous intronic retroviruses on MHC class II diversity and stability. Journal of Virology 82, 6667-6677.

Dupressoir, A., Marceau, G., Vernochet, C., Bénit, L., Kanellopoulos, C., Sapin, V., \& Heidmann. T. (2005). Syncytin-A and syncytin-B, two fusogenic placenta-specific murine envelope genes of retroviral origin conserved in Muridae. Proceedings of the National Academy of Sciences of the USA 102(3), 725-730.

Eigen, M., \& Winkler, R. (1983). The laws of the game: How the principles of nature govern chance. London: Penguin Books.

Flockerzi, A., Burkhardt, S., Schempp, W., Meese, E., \& Mayer, J. (2005). Human endogenous retrovirus HERV-K14 families: Status, variants, evolution, and mobilization of other cellular sequences. Journal of Virology 79, 2941-2949.

Gillespie-Lynch, K., Greenfield, P. M., Lyn, H., \& Savage-Rumbaugh, S. (2014). Gestural and symbolic development among apes and humans: Support for a multimodal theory of language evolution. Frontiers in Psychology 5, 1228, 1-10.

Gootwine, E. (2004). Placental hormones and fetal-placental development. Animal Reproduction Sciences 82-83, 551-566.

Graham, K. E., Hobaiter, C., Ounsley, J., Furuichi, T., \& Byrne, R. W. (2018). Bonobo and chimpanzee gestures overlap extensively in meaning. PLoS Biology 16(2), 1-18.

Habermas, J. (1984). The theory of communicative action. Reason and the rationalization of society (Vol. 1). Boston: Beacon Press.

Habermas, J. (1987). The theory of communicative action. Lifeworld and system: A critique of functionalist reason (Vol. 2). Boston: Beacon Press.

Hobaiter, C., \& Byrne, R. W. (2014). The meanings of chimpanzee gestures. Current Biology 24, 1596-1600.

Page 15 of 19

PRINTED FROM OXFORD HANDBOOKS ONLINE (www.oxfordhandbooks.com). (C) Oxford University Press, 2018. All Rights Reserved. Under the terms of the licence agreement, an individual user may print out a PDF of a single chapter of a title in Oxford Handbooks Online for personal use (for details see Privacy Policy and Legal Notice). 


\section{How viruses made us humans}

Hoffmann, D. L., Standish, C. D., García-Diez, M., Pettitt, P. B., Milton, J. A., Zilhão, J., Alcolea-González, J. J., Cantalejo-Duarte, P., Collado, H., de Balbín, R., Lorblanchet, M., Ramos-Muñoz, J., Weniger, G. Ch., \& Pike A. W. G. (2018). U-Th dating of carbonate crusts reveals Neandertal origin of Iberian cave art. Science 359, 912-915.

Jurka, J., Kapitanov, V. V., Kohany O., \& Jurka, M. V. (2007). Repetitive sequences in complex genomes: Structure and evolution. Annual Review of Genomics and Human Genetics 8, 241-259.

Kendrick, K. M. (2006). The neurobiology of social recognition, attraction and bonding. Philosophical Transactions of the Royal Society B 361, 2057-2059.

Kim, T. M., Hong, S. J., \& Rhyu, M. G. (2004). Periodic explosive expansion of human retroelements associated with the evolution of the hominoid primate. Journal of Korean Medical Sciences 19, 177-185.

Kulski, J. K., Gaudieri, S., Inoko, H., Dawkins, R. L. (1999). Comparison between two human endogenous retrovirus (HERV)-rich regions within the major histocompatibility complex. Journal of Molecular Evolution 48, 675-683.

Lambowitz, A. M., \& Zimmerly, S. (2011). Group II introns: Mobile ribozymes that invade DNA. Cold Spring Harbor Perspectives in Biology 3(8), 1-19.

Liszkowski, U., Schäfer, M., Carpenter, M., \& Tomasello, M. (2009). Prelinguistic infants, but not chimpanzees, communicate about absent entities. Psychological Science 20, 654660 .

Marraffini, L. A. \& Sontheimer, E. J. (2010). Self versus non-self discrimination during CRISPR RNA-directed immunity. Nature 463(7280), 568-571.

Mead, G. H. (1934). Mind, self, and society. Chicago: The University of Chicago Press.

Mitchell, R. S., Beitzel, B. F., Schroder, A. R., Shinn, P., Chen, H., Berry, C. C., Ecker, J. R., \& Bushman, F. D. (2004). Retroviral DNA integration: ASLV, HIV, and MLV show distinct target site preferences. PLoS Biology 2(8), 1127-1137.

Montagu, J. (2017). How music and instruments began: A brief overview of the origin and entire development of music, from its earliest stages. Frontiers in Sociology 2(8), 1-12.

Nirenberg, M., Leder, P., Bernfield, M., Brimacombe, R., Trupin, J., Rottman, F., \& O’Neal, C. (1965). RNA codewords and protein synthesis, VII. On the general nature of the RNA code. Proceedings of the National Academy of Sciences of the United States of America $53,1161-1168$.

Nowak Martin, A. N., Komarova, N. L., \& Niyogi, P. (2001). Evolution of universal grammar. Science 291, 114-118.

Page 16 of 19

PRINTED FROM OXFORD HANDBOOKS ONLINE (www.oxfordhandbooks.com). (c) Oxford University Press, 2018. All Rights Reserved. Under the terms of the licence agreement, an individual user may print out a PDF of a single chapter of a title in Oxford Handbooks Online for personal use (for details see Privacy Policy and Legal Notice). 


\section{How viruses made us humans}

Peirce, C. S. (1923). How to make our ideas clear. In M. E. Cohen (Ed.), Chance, love, and logic: Philosophical essays (pp. 32-60). New York: Harcourt, Brace and World.

Perot, P., Bolze, P. A., \& Mallet, F. (2012). From viruses to genes: Syncytins. In G. Witzany (Ed.), Viruses: Essential agents of life (pp. 325-361). Dordrecht: Springer.

Rohwer, F., Youle, M., Maughan, H., \& Hisakawa, N. (2014). Life in our phage world. San Diego: Wholon.

Roossinck, M. J. (2015). Metagenomics of plant and fungal viruses reveals an abundance of persistent lifestyles. Frontiers in Microbiology 5, 1-3.

Russon, A. E., \& Begun, D. R. (2004). The evolution of thought: Evolutionary origins of great ape intelligence. Cambridge: Cambridge University Press.

Ryan, F. (2009). Virolution. London Haper and Collins.

Searle, J. R. (1976). Speech acts. An essay in the philosophy of language. Cambridge: Cambridge University Press.

Shannon, C. E., \& Weaver, W. (1949). The mathematical theory of communication. Urbana, IL: University of Illinois Press.

Shapiro, J. A. (2002). Repetitive DNA, genome system architecture and genome reorganization. Research in Microbiology 153, 447-453.

Shapiro, J. A., \& von Sternberg, R. (2005). Why repetitive DNA is essential to genome function. Biological Reviews 80, 227-250.

Shepherd, J. D. (2017). Arc-An endogenous neuronal retrovirus? Seminars in Cell \& Developmental Biology pii: S1084-S9521(17), 30471-30478.

Spehr, M., Kelliher, K. R., Li, X.-H., Boehm, T., Leinders-Zufall, T., \& Zufall, F. (2006). Essential role of the main olfactory system in social recognition of major histocompatibility complex peptide ligands. Journal of Neurosciences 26, 1961-1970.

Tomasello, M. (1999). The cultural origins of human cognition. Cambridge, MA: Harvard University Press.

Tomasello, M. (2003a). Constructing a language: A usage-based theory of language acquisition. Cambridge, MA: Harvard University Press.

Tomasello, M. (2003b). On the different origins of symbols and grammar. In M. H. Christiansen \& S. Kirby (Eds.), Language evolution (pp. 94-110). Oxford: Oxford University Press.

Tomasello, M. (2008). Origins of human communication. Cambridge, MA: MIT Press.

Page 17 of 19

PRINTED FROM OXFORD HANDBOOKS ONLINE (www.oxfordhandbooks.com). (C) Oxford University Press, 2018. All Rights Reserved. Under the terms of the licence agreement, an individual user may print out a PDF of a single chapter of a title in Oxford Handbooks Online for personal use (for details see Privacy Policy and Legal Notice). 


\section{How viruses made us humans}

Tomasello, M. (2014). A natural history of human thinking. Cambridge, MA: Harvard University Press.

Tomasello, M., Carpenter, M., Call, J., Behne, T., \& Moll, H. (2005). Understanding and sharing intentions: The origins of cultural cognition. Behavioral and Brain Sciences 28, 675-735.

Tomasello, M., \& Rakoczy, H. (2003). What makes human cognition unique? From individual to shared to collective intentionality. Millennial Perspective Series in Mind and Language 18, 121-147.

Villarreal, L. P. (2004). Can Viruses Make Us Human? Proceedings of the American Philosophical Society 148(3), 296-323.

Villarreal, L. P. (2005). Viruses and the evolution of life. Washington: ASM Press.

Villarreal, L. P. (2009a). Origin of group identity: Viruses, addiction and cooperation. New York: Springer.

Villarreal, L. P. (2009b). The source of self: genetic Parasites and the origin of adaptive immunity. Annals of the New York Academy of Sciences 1178, 194-232.

Villarreal, L. P. (2011a). Viral ancestors of antiviral systems. Viruses 3, 1933-1958.

Villarreal, L. P. (2011b). Viruses and host evolution: virus-mediated self identity. In C. Lopez-Larrea (Ed.), Self and non-self (pp. 1-34). Austin: Landes Bioscience and Springer Science+ Business Media.

Villarreal, L. P. (2015a). Virolution can help us understand the origin of life. In V. Kolb (Ed.), Handbook of astrobiology (pp. 421-440). Boka Raton: CrC Press.

Villarreal, L. P. (2015b). Can virolution help us understand recent human evolution? In V. Kolb (Ed.), Handbook of astrobiology (pp. 441-472). Boka Raton: CrC Press.

Villarreal, L. P., \& Witzany, G. (2010). Viruses are essential agents within the roots and stem of the tree of life. Journal of Theoretical Biology 262, 698-710.

Villarreal, L. P., \& Witzany, G. (2015). When competing viruses unify: Evolution, conservation, and plasticity of genetic identities. Journal of Molecular Evolution 80, 305.

von Frisch, K. (1971). Bees: Their vision, chemical senses and language. Ithaca: Cornell University Press.

von Neumann, J. (1966). Theory of self-reproducing automata. In W. B. Arthur (Ed.), (pp. 64-87). Urbana \& London: University of Illinois Press.

Weiner, A. M. (2006). SINEs and LINEs: Troublemakers, saboteurs, benefactors, ancestors. In R. F. Gesteland, T. R. Cech, \& J. F. Atkins (Eds.), The RNA World (3rd ed). (pp. 507-533). New York: Cold Spring Harbor Laboratory Press.

Page 18 of 19

PRINTED FROM OXFORD HANDBOOKS ONLINE (www.oxfordhandbooks.com). (C) Oxford University Press, 2018. All Rights Reserved. Under the terms of the licence agreement, an individual user may print out a PDF of a single chapter of a title in Oxford Handbooks Online for personal use (for details see Privacy Policy and Legal Notice). 


\section{How viruses made us humans}

Wiener, N. (1948). Cybernetics: Or control and communication in the animal and the machine. Cambridge, MA: MIT Press.

Wittgenstein, L. (1922). Tractatus Logico Philosophicus. Logisch-philosophische Abhandlung. London: Kegan Paul.

Wittgenstein, L. (1953). Philosophical investigations. Oxford: Basil Blackwell.

Witzany, G. (2010a). Biocommunication and natural genome editing. Dordrecht: Springer.

Witzany, G. (Ed.) (2010b). Natural genetic engineering and natural genome editing. Hoboken: Wiley Blackwell.

Witzany, G. (Ed.) (2011). Biocommunication in soil microorganisms. Heidelberg: Springer.

Witzany, G. (Ed.) (2012a). Biocommunication of fungi. Dordrecht: Springer.

Witzany, G. (Ed.) (2012b). Viruses: Essential agents of life. Dordrecht: Springer.

Witzany, G. (Ed.) (2014). Biocommunication of animals. Dordrecht: Springer.

Witzany, G. (2017a). Biocommunication of archaea. Dordrecht: Springer.

Witzany, G. (2019). Communication as the main characteristic of life. In V. Kolb (Ed.), Handbook of astrobiology (pp. 91-105). Boka Raton: CrC Press.

Witzany, G. (Ed.) (2020). Biocommunication of phages. Cham: Springer.

Witzany, G., \& Baluska, F. (Eds.) (2012). Biocommunication of plants. Heidelberg: Springer.

Witzany, G., \& Nowacki, M. (2016). Biocommunication of ciliates. Dordrecht: Springer.

Youle, M., Haynes, M., \& Rohwer, F. (2012). Scratching the surface of biology's dark matter. In G. Witzany (Ed.), Viruses: Essential agents of life (pp. 61-81). Dordrecht: Springer.

Zilhão, J., Angelucci, D. E., Badal-García, E., d’Errico, F., Daniel, F., Dayet, L., Douka, K., Higham, T. F., Martínez-Sánchez, M. J., Montes-Bernárdez, R., Murcia-Mascarós, S., Pérez-Sirvent, C., Roldán-García, C., Vanhaeren, M., Villaverde, V., Wood, R., Zapata, J. (2010). Symbolic use of marine shells and mineral pigments by Iberian Neandertals. Proceedings of the National Academy of Sciences of the USA 107, 1023-1028.

\section{Guenther Witzany}

Telos-Philosophische Praxis

Page 19 of 19

PRINTED FROM OXFORD HANDBOOKS ONLINE (www.oxfordhandbooks.com). (C) Oxford University Press, 2018. All Rights Reserved. Under the terms of the licence agreement, an individual user may print out a PDF of a single chapter of a title in Oxford Handbooks Online for personal use (for details see Privacy Policy and Legal Notice). 